\title{
Srovnávací analýza typů nonverbálních prvků v současných českých a německých učebnicích školní geografie ${ }^{1}$
}

\author{
Tomáš Janko \\ Masarykova univerzita, Pedagogická fakulta, Institut výzkumu školního vzdělávání
}

Redakci zasláno 18. 8. 2014 / upravená verze obdržena 24. 1. 2015 / k uveřejnění přijato 6. 2. 2015

\begin{abstract}
Abstrakt: Studie usiluje o porovnání aktuálních českých a německých učebnic školní geografie z hlediska zastoupení typů nonverbálních prvků a interpretaci zjištění vzhledem $\mathrm{k}$ cílovému zaměření daného vyučovacího předmětu. Nejdříve je $\mathrm{v}$ obecné rovině poukazováno na okolnosti, s nimiž se učebnice školní geografie musejí vypořádávat $\mathrm{v}$ souvislosti $\mathrm{s}$ transformováním stále komplexnějších geografických poznatků. Následně je v teoretické rovině objasňována pozice, již v tomto ohledu zaujímají nonverbální prvky (obrazová složka učebnic). Výklad se opírá o teorii učebnic a koncept reprezentace učiva. Představeny jsou také cílové domény školní geografie, které současně slouží jako interpretační rámec pro výzkumná zjištění. Studie byla realizována jako obsahová analýza 2 českých a 2 německých učebnic školní geografie (ISCED 2), ve kterých bylo analyzováno celkem 1140 nonverbálních prvků. Výsledky studie naznačují, že v českých učebnicích školní geografie stále dominují obrazové typy nonverbálních prvkủ. Naproti tomu v německých učebnicích školní geografie lze zastoupení typů nonverbálních prvků hodnotit jako vyvážené. Ukazuje se tak, že v aktuálních českých učebnicích, na rozdíl od německých, i nadále převažují především nonverbální prvky, které jako didaktické prostředky odkazují spíše k afektivní cílové doméně. Žáky motivují k emocionálním prožitkům, ale samy o sobě nemusejí vybízet k hlubšímu interagování se vzdělávacími obsahy.
\end{abstract}

Klíčová slova: školní geografie, učebnice, nonverbální prvky, vizuální reprezentace, srovnávací analýza, didaktická transformace

Život v lidské společnosti přináší mnohé otázky, jejichž odpovědi je nutné hledat ve vzájemných souvislostech. Mezi obory umožňující objasňování zákonitosti interakce lidského společenství s životním prostředím patří i geografie.

1 Vznik studie byl podpořen $\mathrm{z}$ projektu Zaměstnáním čerstvých absolventů doktorského studia $k$ vědecké excelenci (CZ.1.07./2.3.00/30.0009), který je spolufinancován Evropským sociálním fondem a státním rozpočtem České republiky. 
Zvyšující se objem geografického poznání ale klade nároky na to, jak získané informace efektivně zprostředkovávat. Rozsah a aktuálnost geografických poznatků však hrají zásadní roli i z hlediska školního vzdělávání. V rovině školní geografie totiž mohou vést k přehodnocování vzdělávacích obsahů, ale také potřebě zamýšlet se nad „efektivností" stávajících didaktických prostředků. $\mathrm{V}$ příspěvku je $\mathrm{v}$ tomto ohledu pozornost zaměřována na učebnice školní geografie ${ }^{2}$, u nichž požadavky na reprezentování stále komplexnějšího učiva vyvolávají důležité změny - v jejich struktuře se vzhledem k větší univerzálnosti při transformování učiva stále významněji prosazuje nonverbální komponenta. Se vzrůstající frekvencí se tak lze setkat s empiricky ověřenými tvrzeními o vizuálním obratu (resp. „záplavě obrázkư") v učebnicích (např. Wessel, 2010, s. 234).

Přínos nonverbální komponenty učebnic při učení ale není samozřejmostí. Jedním z rozhodujících faktorů je didaktické ztvárnění, jež je nejzřetelněji patrné u nonverbálních prvků (Peeck, 1993, s. 227-229). Podoba nonverbálních prvků v učebnicích je však často ovlivňována didaktickými tradicemi a může tak vykazovat specifika, pokud jde o mezinárodní srovnání (srov. Erdmann, 2010, s. 150-151). Specifika spočívají v tom, do jaké míry jsou vlastnosti nonverbálních prvků promýšleny s ohledem na rozvíjení znalostních struktur žáků při učení (Tang, 1994, s. 192-193). Studií, které by při analyzování problematiky nonverbálních prvků v učebnicích usilovaly o integrující (mezinárodní) nadhled, je však nedostatek. Poznatky napomáhající k systematickému objasňování edukačního potenciálu nonverbálních prvků v učebnicích tak nejsou k dispozici v uspokojujícím množství.

Studie, vzhledem $\mathrm{k}$ předmětu jejího zájmu, poukazuje na provázanost mezi vyučovacím předmětem zeměpis a vědním oborem geografie. Uchopování tohoto vztahu skrývá řadu úskalí a předpokládá proto adekvátní operování s triádou souvisejících pojmů: geografie - školní geografie - zeměpis, jejichž prostřednictvím může být čtenáři přibližováno, na jaké úrovni problematiky se nachází. $V$ teoretické části studie proto rozlišujeme mezi pojmy geografie (jsou-li akcentovány vazby k vědnímu oboru) a školní geografie (jsou-li zdůrazňovány vazby ke školní výuce). V určitých pasážích studie by však použití zmiňovaných pojmů nebylo plně odpovídající (např. metodologická část, výsledková část). Proto vyžadujeli si to logika výkladu, je používán pojem zeměpis, resp. jeho alternativy (např. učebnice sociálního zeměpisu). 


\section{Teoretická východiska}

Ukotvení studie vychází z teorie učebnic a konceptu reprezentací učiva (kap. 1.1; kap. 1.2). Objasňující kontext pro interpretaci výzkumných zjištění však představuje také pojetí geografie jako vědní disciplíny (kap. 1.3).

\subsection{Nonverbální prvky jako klíčová složka učebnic školní geografie}

Složitá povaha geografických jevů mnohdy nedovoluje, aby s nimi žáci získali bezprostřední zkušenost. Porozumění geografickým poznatkům proto nemusí být vždy jednoduchou záležitostí. V rámci školní geografie se tak otevírá prostor pro uplatňování širokého spektra didaktických prostředků. Mezi ty osvědčené, tradičně napomáhající při ujasňování vzdělávacích obsahů, patří školní učebnice. A to i přes dostupnost „modernějších“ edukačních médií (Maňák, 2008, s. 19). Specifické postavení učebnic školní geografie vyplývá ze skutečnosti, že vzhledem ke komplexitě vzdělávacích obsahů, jež musejí zprostředkovávat, se u nich mnohem významněji projevuje reprezentační a strukturující funkce (Haubrich, 2006, s. 184). To v praxi znamená, že na učebnice školní geografie jsou kladeny vyšší požadavky, pokud jde o didaktickou vybavenost, respektive kognitivní či umělecko-estetické parametry. Jejich rozpoznávacím znakem se tak stává bohaté zastoupení různých reprezentačních formátů, které ovlivňují, zda se žáci (resp. učitelé) budou určitou pasáží (učivem) zabývat podrobněji, nebo ji přejdou bez povšimnutí (Woodward, 1993, s. 118-119). Úspěšné osvojování učiva školní geografie však mnohdy závisí i na tom, v jaké míře konkrétnosti je žákům zprostředkováváno (srov. Levin, 1976, s. 119). Klíčovou složku učebnic školní geografie, proto představují nonverbální prvky, které na obtížně uchopitelné geografické jevy nabízejí koncentrovaný a zároveň více výstižný pohled (srov. Wahla, 1983, s. 37-38). Důležitou roli v tomto ohledu hraje bezesporu výběr obsahů nonverbálních prvků (např. Rose, 2008, s. 155-156). Zásadním předpokladem jsou však i didaktické kvality nonverbálních prvků, jež by bylo možné charakterizovat jako vlastnosti různorodého charakteru (sémantické, syntaktické, umělecké aj.), podmiňující fungování nonverbálních prvků při transformování učiva. ${ }^{3} \mathrm{Z}$ hlediska porozumění geografickým poznatkům představuje zásadní kvalitu typ nonverbálního prvku. Ten nejzřetelněji vyjadřuje souhru dílčích vlastností (např. množství detailů, míru konkrétnosti ad.)

3 V odborné literatuře jsou proto rozpracovávány taxonomie, které v různé míře podrobnosti vymezují kvality nonverbálních prvků, odkazující k různým pedagogickým, psychologickým aj. parametrům (např. Pešková, 2012, s. 43-44 ad.). 
a na pozadí ostatních kvalit naznačuje možnosti konkrétního didaktického využití (srov. Mikk, 2000, s. 279). Jednotlivé typy nonverbálních prvků jsou však kognitivně zpracovávány odlišným způsobem a mohou proto odkazovat k různým učebním aktivitám. V současných učebnicích školní geografie se tak lze setkat s množstvím rozmanitých typů nonverbálních prvků, o jejichž didaktickém fungování je ale k dispozici spíše omezené množství poznatků.

\subsection{Význam nonverbálních prvků při transformování geografických poznatků}

Plnohodnotné porozumění geografickým jevům obvykle vyžaduje nejen rozpoznávání příčin a důsledků, ale také uvědomování si souvisejících procesů. Důležitým předpokladem se proto stává schopnost myšlenkového pohybu od analytického k obecnému pohledu a zpět. Pro žáky (zejména v nižších ročnících) však takovéto uvažování může být poměrně obtížné, nebot' ne vždy dokáží odlišit podstatné aspekty geografických jevů od těch méně důležitých. Úloha nonverbálních prvků v učebnicích školní geografie by proto měla spočívat především v tom, že dokáží zmiňované myšlenkové činnosti žáků aktivizovat a rozvíjet. Nonverbální prvky k tomu mají nezanedbatelný didaktický potenciál ${ }^{4}$, protože seznamování žáků s geografickými jevy podporují na více navzájem provázaných úrovních (viz dále).

Nejvíce patrný je př́inos nonverbálních prvků v doméně poznávací (kognitivní). Ve školních učebnicích se totiž uplatňují jako vnější obrazové reprezentace, které na základě analogie postihují hlavní znaky a strukturu geografických jevů a ty tak mohou být „rozloženy“ do srozumitelnějších částí. Užitečné jsou přitom zejména nonverbální prvky propracované a zároveň dobře strukturované (napřr průřez geografickým jevem s časovou řadou). Ty u žáků zpravidla vyvolávají bohatší myšlenkové asociace, jež následně napomáhají přirozenému propojování nových informací s tím, co už žák zná. Podle Tollingerové (1977, s. 225) tak může být podpořeno pronikání smyslového poznání (vidění) a pojmového vědění, což za určitých okolností vyúst’uje k přesnějším představám žáků - mentálním reprezentacím (srov. Sumfleth \& Telgenbüscher, 2000, s. 75-76).

\footnotetext{
Pojem potenciál odkazuje ke skutečnosti, že fungování nonverbálních prvků na zmiňovaných rovinách nemusí být samozřejmostí. Naopak pravděpodobné je za předpokladu součinnosti dalších faktorů, mezi které patří například zkušenost učitele, jeho př́istup $\mathrm{k}$ výuce či pedagogická invence a dovednosti. Zásadním aspektem jsou však také schopnosti a kognitivní předpoklady žáků (srov. Macek, 1984, s. 455; Janko, 2012, s. 47-49).
} 
V současnosti se však nároky na fungování nonverbálních prvků v učebnicích mohou zvyšovat. Na významu tak nabývá i jejich uplatňování v dalších rovinách. Jde zde o to, že promyšlené zapojování nonverbálních prvků do výuky může ovlivňovat pocity žáků týkající se vzdělávacích obsahů (libost či nelibost). Vedle jejich významu při zvyšování zájmu o učivo tak nonverbální prvky mohou hrát důležitou roli i při sbližování představ žáků a učitele a pomáhat tak jejich souladu při společném plnění učebních úkolů. Týká se to např́iklad realistických nonverbálních prvků (např. „chytlavé“ a dostatečně velké fotografie, kresby ad.). Spojitost nonverbálních prvků s emocionální oblastí by však bylo možné ilustrovat i příkladem odkazujícím k multikulturnímu smýšlení v geografii. Nonverbální prvky totiž vzhledem k jejich „univerzální" symbolice napomáhají předávání obecně platných principů a zásad mezi generacemi a usnadňují tak přenášení hodnot a pravidel z jedné společnosti do druhé (srov. Wessel, 2010, s. 234-235).

Důležité je však i to, že nonverbální prvky zprostředkovávají informace způsobem, jenž je již určitým způsobem „předstrukturován“ vzhledem ke schopnostem žáků. Mohou se tak uplatňovat jako specifické vizuální modely (reprezentace), které zprostředkovávají vzdělávací obsahy, ale zároveň, na druhé straně, mohou ovlivňovat učební reakce žáků. Působí tak na rozhodování žáků (i učitelů), jež v ideálním případě vyúst'uje ke konkrétním činnostem a tvůrčím aktivitám. Nonverbální prvky však mohou sloužit stejně dobře jako specifický druh zpětné vazby informující žáka o správnosti jeho myšlení a jednání. Řešením nicméně nemusí být vždy jen důsledný realismus v nonverbálních prvcích, nýbrž důležité jsou i nonverbální prvky, které dokáží vystihnout typické znaky a znázornit tak nejen strukturu, ale zároveň i vývoj podstaty geografických jevů. Př́kladem jsou kombinované nonverbální prvky, které sestávají z více reprezentačních formátů (realistických i abstraktních) a mohou tak žáka intenzivněji vybízet k učebním aktivitám (např. zjednodušený mapový nákres doplněný vysvětlující realistickou kresbou).

Shrnující pohled na uvedené poznatky naznačuje, že význam nonverbálních prvků v učebnicích spočívá mimo jiné v tom, že díky svým vlastnostem dokáží motivovat žáky k aktivnímu interagování s geografickými jevy. To je i v současné době poměrně významné, nebot' tak lze podpořit kritické uvažování žáků o geografických jevech a naopak předcházet pasivnímu přijímání poznatků bez hlubšího pochopení smyslu a souvislostí. Plnohodnotné fungování nonverbálních prvků v těchto rolích ale není samozřejmostí, nýbrž je podmíněno souhrou více faktorů. Zásadní je však zejména schopnost 
žáků nonverbální prvky (a jimi předávané informace) interpretovat, pochopit a případně dále využívat. $\mathrm{Z}$ hlediska školní geografie je potom důležité, aby zastoupení nonverbálních prvků $\mathrm{v}$ učebnicích vycházelo vstříc kognitivním možnostem žáků, ale zároveň korespondovalo se vzdělávacími cíli (srov. Levin \& Mayer, 1993, s. 97).

\subsection{Nonverbální prvky jako prostředky napomáhající při dosahování cílových domén školní geografie}

V kontextu výše uvedených skutečností je úkolem studie ověřit, do jaké míry zastoupení nonverbálních prvků v aktuálních domácích a zahraničních učebnicích koresponduje s cílovým zaměřením školní geografie. Smyslem geografie jako vědecké disciplíny by v obecné rovině mělo být objasňování podmínek, které způsobují proměnlivost přírodních a kulturních jevů na Zemi. Předmětem jejího zájmu se tak stávají vazby mezi lidskými aktivitami a př́irodními podmínkami $\mathrm{v}$ různých regionech (International Geographical Union, 1992, s. 5). Z hlediska vzdělávání jde potom o to, vštípit mladým lidem povědomí o „zákonitostech“ současného dynamicky se vyvíjejícího světa, kteřížto následně (díky tomuto porozumění) mohou zaujmout místo jako vzdělaní členové společnosti (srov. Firth, 2011, s. 290-291). V rovině školní výuky je naplňování tohoto obecného záměru transformováno do cílových domén a výukových metod školní geografie. Ta tak do určité míry funguje jako „klenba“ mezi poznatky geografie jako vědních oborů na jedné straně a představami žáků na straně druhé.

Svébytná pozice školní geografie v systému školního vzdělávání vede k tomu, že její cílové domény reprezentují poměrně široké spektrum dotýkající se rozmanitých oblastí lidské činnosti. V praxi jsou proto klasifikovány do obecnějších dimenzí, což napomáhá orientaci a může také částečně podporovat jejich naplňování (srov. Demirkaya, 2008, s. 288-289). Pro účely této studie se přikláníme ke klasifikaci Mezinárodní charty geografického vzdělávání, která cílové domény školní geografie operacionalizuje ve třech základních doménách: kognitivní, afektivní a psychomotorické (International Geographical Union, 1992, s. 7-8) ${ }^{5}$. Cílové domény v oblasti kognitivní by podle taxonomie

Taxonomii dle Mezinárodní charty geografického vzdělávání považujeme za vyhovující vzhledem k tomu, že zahrnuje hlavní dimenze kurikula školní geografie a zároveň je dostatečně obecná pro účely obsahové analýzy učebnic. Ve studii je proto využita jako rámec pro interpretaci zjištění týkajících se zastoupení typů nonverbálních prvkủ v českých a německých učebnicích školní geografie (kap. 4). 
měly směřovat k získávání nových znalostí (faktů a generalizací), respektive preciznějšímu strukturování již osvojených poznatků. Žáci by tak měli směřovat k hlubšímu porozumění konceptům školní geografie a následnému poučenému řešení učebních úloh a výukových situací. Cílové domény v oblasti afektivní souvisejí s emocionálními projevy a hodnotovým systémem žáků. Měly by proto odkazovat především k citovému prožívání a osobnostnímu přesvědčení (postoje a hodnoty). V afektivní doméně by však měla být rozvíjena i empatie a zvyšování zájmu. Cílové domény v oblasti psychomotorické se podle taxonomie týkají smyslového učení. Měly by proto směřovat nejen k rozvoji tělesného pohybu (např. práce s nástroji), ale také řečového a tvůrčího projevu a přispívat tak k praktickému využívání geografických poznatků v každodenních situacích.

\section{Dosavadní stav řešení a poznání}

Výzkum edukačního potenciálu učebnic a jejich strukturních komponent představuje poměrně heterogenní oblast, jež je utvářena na základě více poznatkových proudů (srov. Kent et al., 1996, s. 174). Pozice této studie je nejblíže pracím, které se (při rozvíjení zmiňované výzkumné oblasti) zaměřují na grafický vzhled učebnic a usilují tak například o posuzování nonverbálních reprezentací v učebnicích a jejich efektivnosti při učení. V následujícím přehledu jsou představovány práce, které $\mathrm{v}$ souvislosti s rozvíjením problematiky nonverbálních prvků v učebnicích usilovaly o podobný přístup.

Souvislost mezi pojetími geografie jako vědecké disciplíny a obsahem učebnic školní geografie analyzoval Jennings (2006). Konkrétně bylo ověřováno, jak se v učebnicích z různých historických období odrážely změny ve standardech geografického vzdělávání (resp. paradigmatech geografie jako vědní disciplíny). Na základě obsahové analýzy šesti amerických učebnic pro školní fyzickou geografii (ISCED 3) publikovaných v rozmezí let 19012002 se ukázalo, že změny v pojetí geografických standardů se v učebnicích projevovaly především ve složení vzdělávacích obsahů a způsobech jejich prezentování. V důsledku toho podle Jenningse (2006) došlo také k určité standardizaci v struktuře učebnic, která je nyní sice „vstřícná“ k inovacím, zároveň ale do určité míry „svazuje“ možnosti učitelů a žáků během výuky. Podobně Yang (2011) zjišt’oval, jak se nově zaváděné standardy a cíle geografického vzdělávání projevují ve struktuře čínských učebnic pro vyšší stupeň 
sekundárního vzdělávání (ISCED 2) ${ }^{6}$. Závěry naznačují, že zavádění standardů mělo $\mathrm{v}$ analyzovaných učebnicích vliv především na složení výukových témat a způsoby jejich reprezentování. V čínských učebnicích vycházejících ze standardů je upřednostňováno spíše širší spektrum geografických témat, jež jsou navzájem provázána, na druhou stranu jsou ale zpracována méně do hloubky. Zároveň došlo k omezení obtížných a časově náročných témat, která by ale žáky seznamovala s moderními geografickými technologiemi a postupy. Srovnání portugalských učebnic pro školní geografii a biologii z hlediska souladu s cíli environmentálního vzdělávání provedli Tracane et al. (2008). Konkrétně autoři zjištovali, jaké výrazové prostředky se v učebnicích uplatňují při reprezentování výukového tématu znečištění. Výsledky analýzy devíti učebnic pro výuku na nižším a vyšším stupni sekundárního vzdělávání (ISCED 2 a 3) naznačily, že portugalské učebnice školní geografie a biologie se odlišovaly nejen $v$ tom, jaká témata environmentálního vzdělávání žákům nabízely, ale také $\mathrm{v}$ tom, jaké výrazové prostředky $\mathrm{k}$ tomu využívaly. V př́ípadě učebnic školní geografie se při reprezentování environmentálních témat uplatňovaly především popisné typy nonverbálních prvků, zatímco nonverbální prvky, které by na žáky působily v rovině afektivní či psychomotorické měly poměrně nízké zastoupení.

Srovnávací analýzu učebnic školní geografie z pěti států z hlediska zastoupení typů nonverbálních prvků provedl Wahla (1983). Výzkumný vzorek tvořilo třicet učebnic pro základní školy (ISCED 1 a 2) z BLR, ČSSR, NDR, PLR, SSSR. Bylo zjištěno, že největší odlišnosti mezi učebnicemi analyzovaných států panovaly v zastoupení obrazových (podíl v rozmezí 50-80 \%), statistických (podíl v rozmezí 7-25\%) a kartografických typů nonverbálních prvků (podíl v rozmezí 5-15 \%). Největší frekvenci obrazových typů nonverbálních prvků vykazovaly československé učebnice, zatímco statistické a kartografické typy nonverbálních prvků převládaly v učebnicích NDR. Podobně Mikk (2000) prostřednictvím obsahové analýzy porovnával estonskou, finskou, německou a rakouskou učebnici chemie pro nižší stupeň sekundárního vzdělávání (ISCED 2). Vycházel přitom z předpokladu, že prezentování učiva žákům prostřednictvím neznámých symbolů může inhibovat učení. $Z$ výsledků vyplývá, že největší četnost abstraktních typů nonverbálních prvků vykazovala estonská učebnice. Naproti tomu nejméně abstraktních typů nonverbálních prvků obsahovaly učebnice německá a finská.

6 Ve výzkumu Yanga byly komparovány 3 tradiční učebnice s „předepsaným“ složením vzdělávacích obsahů a 3 nové učebnice vycházející obsahově z aktualizovaných geografických standardů (Yang, 2011, s. 122). 
Uvedený přehled naznačuje, že pojednávaná problematika je v současnosti rozvinuta jako poměrně různorodé výzkumné pole. Dochází sice ke snahám o objasňování potenciálu nonverbálních prvků vzhledem k cílovým doménám vyučovacích předmětů, v převážné míře se však výzkumné úsilí odhodlává pouze $\mathrm{k}$ informování ohledně didaktické vybavenosti učebnic. Výzkumy týkající se problematiky jsou také realizovány převážně jako izolovaná šetření. Dostupné poznatky je proto poměrně obtížné zasazovat do širších souvislostí. Rozšíření explanačního potenciálu by proto pomohlo, pokud by poznatky týkající se problematiky nonverbálních prvků v učebnicích byly propojovány více systematicky, např. prostřednictvím mezinárodního nadhledu.

\section{Metodologie}

\subsection{Výzkumné cíle a otázky}

Hlavním cílem studie je provedení srovnávací analýzy vybraných českých a německých učebnic školní geografie (obsahujících sociálněgeografická témata) z hlediska typů nonverbálních prvků. Dílčím cílem je ověření, do jaké míry zastoupení typů nonverbálních prvků v daných učebnicích koresponduje s cílovým zaměřením školní geografie. Výzkumné cíle studie jsou konkretizovány výzkumnými otázkami:

a) Jakými typy nonverbálních prvků jsou vybaveny české učebnice školní geografie (obsahující sociálně geografická témata) za účelem didaktické transformace vzdělávacích obsahů?

b) Do jaké míry se české a německé učebnice školní geografie odlišují, pokud jde o zastoupení typů nonverbálních prvků?

c) Ukazují se na základě analýzy vybraných českých a německých učebnic nějaké souvislosti mezi zastoupením typů nonverbálních prvků a cílovým zaměřením školní geografie?

\subsection{Výzkumný vzorek}

Výzkumný vzorek tvořily 2 české a 2 německé učebnice školní geografie pro nižší stupeň sekundárního vzdělávání (ISCED 2), ve kterých bylo posouzeno celkově 1140 nonverbálních prvkư7 . Volba vzorku - záměrným výběrem

7 Z celkového počtu analyzovaných nonverbálních prvků na české učebnice připadalo 608 prvků a na učebnice německé 532 prvků. 
- vyplynula z koncepce šetření, které bylo realizováno jako výzkumná sonda usilující o zprostředkování empirických poznatků pro diskusi o kvalitách nonverbálních prvků $\mathrm{v}$ učebnicích školní geografie. Na učebnice obsahující sociálněgeografická témata jsme se zaměřili proto, že učivo v nich obsažené je poměrně abstraktní a pro žáky může být obtížně uchopitelné (např. mezinárodní obchod). Jeho srozumitelné zprostředkovávání proto klade vyšší nároky na vybavenost učebnic. Výchozím kritériem pro výběr českých učebnic byla orientace na nižší stupeň sekundárního vzdělávání (ISCED 2). Doplňujícím kritériem bylo získání schvalovací doložky MŠMT. Schvalovací doložka byla zohledňována jako indikátor, který má významnou úlohu při regulaci na trhu s učebnicemi a může rovněž odkazovat ke kvalitě učebnic (Greger, 2005, s. 112). Při výběru německých učebnic byla kritériem dostupnost (stejně jako orientace na sociálněgeografická témata a zaměření na nižší stupeň sekundárního vzdělávání). Orientace v německých učebnicových řadách však může být poněkud obtížnější. Samotný systém vydávání učebnic, tj. proces tvorby, schvalování a výběru učebnic pro školní použití, totiž ve Spolkové republice Německo probíhá na úrovni jednotlivých spolkových zemí (Greger, 2005, s. 112). Volba konkrétních německých učebnic (viz dále) proto byla provedena na základě konzultace se zahraničními odborníky v oblasti didaktiky školní geografie ${ }^{8}$. Při výběru českých i německých učebnic bylo uplatněno kritérium aktuálnosti; byly zahrnuty učebnice školní geografie, jejichž doba publikování nebyla delší než 11 let $^{9}$. Na základě uvedených kritérií byly do výzkumného vzorku zahrnuty české učebnice:

Marada, M., et al. (2009). Zeměpis 9. Učebnice pro základní školy a víceletá gymnázia. Plzeň: Fraus (učebnice A).

Herink, J., \& Valenta, V., et al. (2004). Současný svět. Učebnice zeměpisu pro základní školy a víceletá gymnázia, pro 8. nebo 9. ročník. Základy společenského, hospodářského a politického zeměpisu, lidé a príroda - životní prostředí. Praha: Nakladatelství České geografické společnosti (učebnice B).

$8 \quad$ Jednalo se o didaktiky školní geografie působící na Institut für Geographie univerzity Friedricha Schillera v Jeně. Na základě konzultace byly pro účely výzkumné sondy vybrány německé učebnice školní geografie (obsahující sociálněgeografická témata) vykazující znaky charakteristické pro zdejší učebnicovou tvorbu a umožňující tak srovnání s vlastnostmi (resp. nedostatky) českých učebnic školní geografie.

9 Zvážíme-li, že perioda pro vydávání „nových“ učebnicových řad jsou cca 4 roky, zahrnuje zvolený interval učebnice posledních dvou "generací“. Lze tak hovořit o aktuálnosti výzkumného vzorku. 
České učebnice byly porovnávány s německými učebnicemi:

Köhler, P., et al. (2009). Terra. Geographie 9. Regelschule Thüringen. Stuttgart: Klett (učebnice C). Birkendorf, Ch., et al. (2005). Terra. Erdkunde 9/10. Realschulen und differenzierende Schulformen. Nordhein-Westfalen. Gotha: Klett (učebnice D).

Autor příspěvku si je vědom, že vybrané německé učebnice nelze, vzhledem $\mathrm{k}$ jejich zaměření dle typu školy, považovat za plně reprezentativní vzorek, což do určité míry limituje sílu výzkumných zjištění. Vybrané učebnice jsou však určeny pro porovnatelný stupeň školního vzdělávání, jejich použití pro účely výzkumné sondy se mu proto jeví jako akceptovatelné.

Žádoucí je také podotknout, že práce s učebnicemi školní geografie může být ve výuce obohacena i dalšími didaktickými prostředky, jež mohou podporovat kognitivní aktivizaci žáků (např. pracovní sešity, školní atlasy, soubory map, on-line materiály ad.). Zapojování těchto prostředků ve výuce ale obvykle sleduje vlastní cíl (ve srovnání s učebnicemi), resp. plní specifické didaktické funkce (např. opakovací, fixační). V souladu s výzkumnými otázkami šetření proto zmiňované prostředky byly zohledňovány spíše jen jako širší kontext.

\subsection{Výzkumný nástroj}

Analýza učebnic školní geografie z hlediska typů nonverbálních prvků byla realizována prostřednictvím kategoriálního systému koncipovaného na základě tzv. racionálního přístupu (Böhm-Kasper, Schuchart, \& Weishaupt, 2009 , s. 84). Finální verze systému obsahovala 17 kategorií pro posuzování typu nonverbálních prvků. Jednotlivé kategorie byly sdruženy do 8 hodnotících tř́íd, což mělo napomoci přesnějšímu klasifikování a lepší validitě získaných dat (Tabulka 1). Během pilotáže se ukázalo, že kategoriální systém splňuje standardní požadavky kladené na výzkumné nástroje pro posuzování nominálních dat a získaná data tak lze považovat za platná (podrobněji Janko, 2012, s. 88-90). 
Tabulka 1

Kategoriální systém pro posuzování typů nonverbálních prvků v učebnicích

\begin{tabular}{lll}
\hline Název tř́́dy & \multicolumn{2}{l}{ Název kategorie } \\
\hline kartografické & T1.1 & mapa \\
\cline { 2 - 3 } & T1.2 & mapový nákres \\
\cline { 2 - 3 } & T1.3 & plán \\
\hline karotgraficko-statistické & T2.1 & kartogram \\
\cline { 2 - 3 } & T2.2 & kartodiagram \\
\hline statisticko-grafové & T3.1 & graf \\
\hline tabulární & T4.1 & tabulka \\
\hline obrazové & T5.1 & fotografie \\
\cline { 2 - 3 } & T5.2 & malba/kresba \\
\cline { 2 - 3 } & T5.3 & reprodukce výtvarného díla \\
\hline schematické & T6.1 & prưrez \\
\cline { 2 - 3 } & T6.2 & schéma \\
\hline ostatní & T7.1 & kartografické značky \\
\cline { 2 - 3 } & T7.2 & logo \\
\cline { 2 - 3 } & T7.3 & jiné znaky, značky \\
\hline kombinované & T8.1 & obrázková kombinace \\
\cline { 2 - 3 } & T8.2 & obrázková řada \\
\hline & &
\end{tabular}

\subsection{Procedura výzkumu}

Studie vychází z pozitivistického přístupu k analýze dokumentů a usiluje proto o systematický, racionální a kvantitativní pohled (srov. Cohen, Manion, \& Morrison, 2011, s. 254). Šetření bylo realizováno jako deskriptivní analýza porovnávající české a německé učebnice školní geografie z hlediska typů nonverbálních prvků napomáhajících při zprostředkovávání a didaktické transformaci geografických poznatků. Výzkumnou metodu představovala deduktivní obsahová analýza. Nonverbální prvky byly posuzovány na základě charakteristických znaků a následně byly klasifikovány do odpovídajících kategorií. To umožnilo usuzovat na zastoupení typů nonverbálních prvků $\mathrm{v}$ učebnicích a následně vyvozovat interpretace vážící se k fungování nonverbálních prvků jako didaktických prostředků. K vyhodnocení sloužily metody deskriptivní statistiky, které poskytly přehled o rozložení a struktuře dat. 


\section{Výsledky}

V následující části jsou prezentovány výsledky šetření. Strukturovány jsou způsobem umožňujícím zodpovězení výzkumných otázek (kap. 2.1). Nejdříve tak popisujeme poznatky první fáze, kde bylo zjišt'ováno, jakými typy nonverbálních prvků jsou vybaveny české učebnice školní geografie - za účelem didaktického transformování geografických poznatků (kap. 4.1). Následně představujeme poznatky druhé fáze šetření, která se zaměřila na porovnání typů nonverbálních prvků v českých a německých učebnicích školní geografie (kap. 4.2).

\subsection{Zastoupení typů nonverbálních prvků v českých učebnicích školní geografie}

Ukázalo se, že dominantní zastoupení má především fotografie (Tabulka 2). Druhým nejčetněji zastoupeným typem byl mapový nákres ( $\mathrm{v}$ učebnici A 4,7 \%, ve srovnání s tím v učebnici B 13,3\%). V zastoupení ostatních typů nonverbálních prvků se však už analyzované učebnice odlišovaly. Zatímco v učebnici A byla třetím nejčetněji zastoupeným typem tabulka (3,9\%) a logo $(3,9 \%)$, v učebnici B zaujímalo třetí místo schéma (12,1\%). Důležitým zjištěním však je, že v obou českých učebnicích byly v nejmenší míře zastoupeny typy nonverbálních prvků jako mapa $(0,0 \% \mathrm{v}$ učebnici $\mathrm{A} ; 0,0 \% \mathrm{~V}$ učebnici $\mathrm{B})$ či průřrez ${ }^{10}(0,3 \%$ v učebnici $A ; 0,0 \%$ v učebnici $B)$.

Důležitá zjištění přineslo i posouzení kombinovaných nonverbálních prvků. $\mathrm{V}$ analyzovaných českých učebnicích převažovaly spíše obrázkové řady $(2,2 \%$ v učebnici $A ; 4,8 \%$ v učebnici $B)$, jež se mohou uplatňovat při vysvětlování vývoje geografických fenoménu v prostoru a čase. Naproti tomu obrázkové kombinace, které mohou zprostředkovávat různé úhly pohledu na geografické jevy, se v učebnicích vyskytovaly spíše ojediněle $(0,3 \%$ v učebnici $A ; 0,0 \%$ v učebnici $B$ ).

Při podrobnějším pohledu je tak patrné, že v českých učebnicích školní geografie převažovaly typy nonverbálních prvků spadajících do třídy obrazové

10 Průřez zde chápeme jako vertikální nebo horizontální řez určitým geografickým jevem. Používání pojmu průřez (resp. geografický průřez) nicméně není jednotné. V některých př́ípadech proto může být nahrazován termínem blokdiagram. Přiklonění se k pojmu průřez v této studii je dáno použitím původní verze výzkumného nástroje (kategoriálního systému), která splnila požadavky na reliabilitu a jejíž integrální součástí daný pojem je (podrobněji Janko, 2012, s. 88-90). 
(76,7 \% v učebnici $A ; 48,8 \%$ v učebnici B). Naproti tomu abstraktní typy nonverbálních prvků náležející do tříd kartografické $(5,0 \% \mathrm{v}$ učebnici $A$; $15,5 \%$ v učebnici $B)$ a schematické $(1,4 \%$ v učebnici $A ; 12,1 \%$ v učebnici B) byly zastoupeny $\mathrm{v}$ menším počtu. Nízké zastoupení bylo zjištěno také u prvků patřících do tříd tabelární (3,9\% v učebnici $A ; 8,1 \%$ v učebnici $B)$ a statisticko-grafové $(3,3 \%$ v učebnici $A ; 7,7 \%$ v učebnici $B)$. V relativně nízkých četnostech byly zastoupeny i prvky ve třídách ostatní $(5,0 \%$ v učebnici A; $0,8 \%$ v učebnici $B)$, kartograficko-statistické $(2,1 \%$ v učebnici $A ; 3,2 \%$ v učebnici B) a kombinované (2,5 \% v učebnici $A ; 4,8 \%$ v učebnici $B)$.

\subsection{Srovnání typů nonverbálních prvků v českých a německých učebnicích školní geografie}

Dále bylo porovnáváno, jak si české učebnice školní geografie stojí z hlediska mezinárodního srovnání. Komparace byla realizována jak na úrovni typů nonverbálních prvků, tak na úrovni tříd. Bylo zjištěno, že podobně jako u českých učebnic školní geografie i u těch německých byla nejvíce zastoupeným typem nonverbálního prvku fotografie. Avšak zatímco u českých učebnic její zastoupení výrazně převládalo $(75,3 \% \mathrm{v}$ učebnici $\mathrm{A} ; 44,8 \% \mathrm{v}$ učebnici $\mathrm{B})$, u německých učebnic se jevilo jako vyvážené $(36,2 \%$ v učebnici C; 22,3 \% v učebnici D). České a německé učebnice vykazovaly podobnost také u nejméně zastoupených typů nonverbálních prvků. Shodně se jednalo o mapu a průřez, jež jsou však při transformování geografických poznatků jen obtížně zastupitelné. Podrobnější srovnání však poukázalo spíše na rozdíly mezi učebnicemi. Zatímco v německých učebnicích se při transformování abstraktních geografických fenoménů uplatňovaly grafy, $v$ českých učebnicích bylo v tomto ohledu spoléháno spíše na schémata. Pokud jde o kombinované nonverbální prvky, jež umožňují znázorňovat vývoj geografických jevů anebo nabízejí různé úhly pohledu, bylo zjištěno, že české učebnice školní geografie potenciálu těchto typů využívají v menší míre, ve srovnání s učebnicemi německými. Rozdíly jsou přitom patrné především u obrázkových řad (Tabulka 2). 
Tabulka 2

Zastoupení typů nonverbálních prvků v českých a německých učebnicích školní geografie

\begin{tabular}{|c|c|c|c|c|c|c|c|c|c|}
\hline \multirow{2}{*}{$\begin{array}{l}\text { třída } \\
\text { nonverbálního } \\
\text { prvku }\end{array}$} & \multirow{2}{*}{$\begin{array}{l}\text { typ nonverbálního } \\
\text { prvku }\end{array}$} & \multicolumn{2}{|c|}{ učebnice A } & \multicolumn{2}{|c|}{ učebnice B } & \multicolumn{2}{|c|}{ učebnice C } & \multicolumn{2}{|c|}{ učebnice D } \\
\hline & & (n) & $(\%)$ & (n) & $(\%)$ & (n) & $(\%)$ & (n) & $(\%)$ \\
\hline \multirow[t]{3}{*}{ kartografické } & mapa & 0 & 0,0 & 0 & 0,0 & 1 & 0,4 & 2 & 0,7 \\
\hline & mapový nákres & 17 & 4,7 & 33 & 13,3 & 40 & 15,7 & 22 & 7,9 \\
\hline & plán & 1 & 0,3 & 3 & 1,2 & 3 & 1,2 & 2 & 0,7 \\
\hline \multirow{2}{*}{$\begin{array}{l}\text { kartograficko- } \\
\text { statistické }\end{array}$} & kartogram & 8 & 2,1 & 6 & 2,4 & 3 & 1,2 & 14 & 5,0 \\
\hline & kartodiagram & 0 & 0,0 & 2 & 0,8 & 1 & 0,4 & 6 & 2,2 \\
\hline statistic.-graf. & graf & 12 & 3,3 & 19 & 7,7 & 30 & 11,8 & 42 & 15,1 \\
\hline tabulární & tabulka & 14 & 3,9 & 20 & 8,1 & 19 & 7,5 & 51 & 18,3 \\
\hline \multirow[t]{3}{*}{ obrazové } & fotografie & 271 & 75,3 & 111 & 44,8 & 92 & 36,2 & 62 & 22,3 \\
\hline & malba/kresba & 1 & 0,3 & 8 & 3,2 & 11 & 4,3 & 19 & 6,8 \\
\hline & $\begin{array}{l}\text { reprodukce } \\
\text { výtvarného díla }\end{array}$ & 4 & 1,1 & 2 & 0,8 & 2 & 0,8 & 9 & 3,2 \\
\hline \multirow[t]{2}{*}{ schematické } & průřrez & 1 & 0,3 & 0 & 0,0 & 8 & 3,1 & 2 & 0,7 \\
\hline & schéma & 4 & 1,1 & 30 & 12,1 & 15 & 5,9 & 17 & 6,1 \\
\hline \multirow[t]{3}{*}{ ostatní } & $\begin{array}{l}\text { kartografická } \\
\text { značka }\end{array}$ & 0 & 0,0 & 0 & 0,0 & 0 & 0,0 & 0 & 0,0 \\
\hline & logo & 14 & 3,9 & 2 & 0,8 & 1 & 0,4 & 6 & 2,2 \\
\hline & další značky & 4 & 1,1 & 0 & 0,0 & 7 & 2,8 & 0 & 0,0 \\
\hline \multirow[t]{2}{*}{ kombinované } & $\begin{array}{l}\text { obrázková } \\
\text { kombinace }\end{array}$ & 1 & 0,3 & 0 & 0,0 & 3 & 1,2 & 5 & 1,8 \\
\hline & obrázková řada & 8 & 2,2 & 12 & 4,8 & 18 & 7,1 & 19 & 6,8 \\
\hline celkem & & 360 & 100 & 248 & 100 & 254 & 100 & 278 & 100 \\
\hline
\end{tabular}

Dále bylo zjišt'ováno, zda (resp. v jaké míře) se od sebe české a německé učebnice školní geografie odlišují, pokud jde o třídy nonverbálních prvků s podobnými sémantickými a syntaktickými charakteristikami. Výsledky neprokázaly, že by se skladba tř́íd nonverbálních prvků v českých učebnicích školní geografie významně lišila od učebnic německých. Různorodost analyzovaných učebnic tak spočívala především $\mathrm{v}$ tom, jak významná role v nich byla jednotlivým třídám nonverbálních prvků přisouzena (Obrázek 1). 


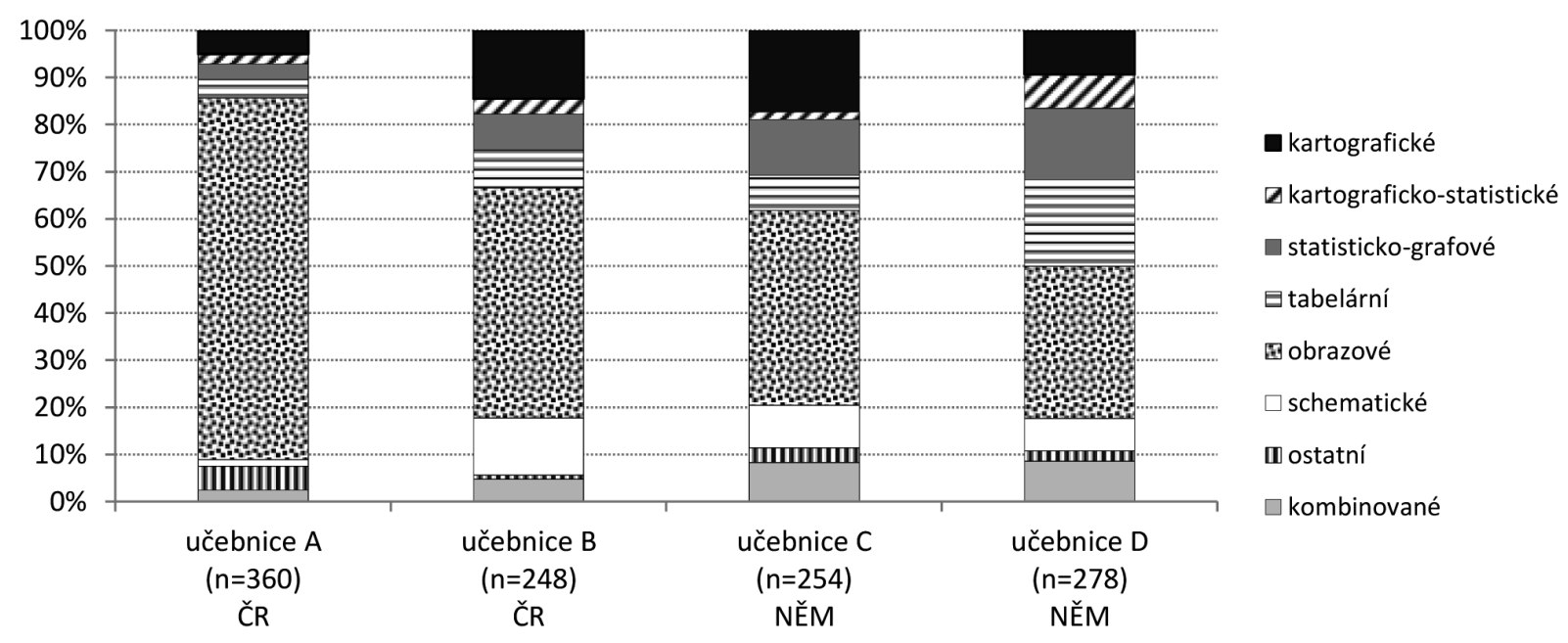

Obrázek 1. Srovnání českých a německých učebnic školní geografie z hlediska zastoupení nonverbálních prvků.

Posuzování tříd nonverbálních prvků má svůj význam, nebot' se tak lze dozvědět, do jaké míry jsou učebnice vyvážené, pokud jde o různé způsoby prezentování geografických jevů, jež nabízejí odlišné úhly pohledu (a mohou tak napomáhat porozumění). Pro přesnější představu o tom, do jaké míry se od sebe české a německé učebnice školní geografie odlišují v zastoupení tříd nonverbálních prvků, byl proto jako doplňující ukazatel vypočítán index nominální variance, který slouží k porovnání variability u nominálních dat (Chráska, 2007, s. 58).

Tabulka 3

Míra odlišnosti mezi českými a německými učebnicemi školní geografie z hlediska typových tříd nonverbálních prvků

\begin{tabular}{lc}
\hline třída & $\begin{array}{c}\text { index } \\
\text { nonverbálních prvků }\end{array}$ \\
\hline kartografické & 0,72 \\
kartograficko-statistické & 0,66 \\
statisticko-grafové & 0,70 \\
tabelární & 0,67 \\
obrazové & 0,69 \\
schematické & 0,69 \\
ostatní & 0,63 \\
kombinované & 0,72 \\
\hline
\end{tabular}


Výsledky naznačily (Tabulka 3), že české a německé učebnice školní geografie se odlišují především v zastoupení trrídy ostatní (nom. var. $=0,6298)^{11}$. Zatímco u českých učebnic bylo zastoupení této třídy poměrně významné, u německých učebnic bylo spíše nižší. Jedná se o zajímavé zjištění, protože třída ostatní obsahuje typy nonverbálních prvků, které se při objasňování učiva uplatňují spíše nepřímo (značky a loga ad.). Jejich význam spočívá spíše v organizaci osvojovaných informací. V učebnicích se však mohou vyskytovat i kvůli zatraktivnění vzhledu. Odlišnost mezi českými a německými učebnicemi se ukázala také u kategorií kartograficko-statistické (nom. var. $=0,66)$ a tabelární (nom. var. $=0,671)$. Př́činou byl vyšší podíl prvků spadajících do těchto tříd v německých učebnicích, ve srovnání s učebnicemi českými. Naopak nejmenší odchylka, pokud jde o třídy nonverbálních prvků (tzn. vysoká hodnota indexu variance) byla v posuzovaných učebnicích zjištěna u kategorií kombinované (nom. var. $=0,7149$ ) a kartografické (nom. var $=0,7182$ ). Nutno však doplnit, že například u kategorie kombinované mohla být nízká míra odlišnosti způsobena celkově nízkým výskytem této třídy ve všech analyzovaných učebnicích.

\subsection{Interpretace zastoupení nonverbálních prvků v českých a německých učebnicích z hlediska cílového zaměření školní geografie}

Jak již bylo uvedeno, úlohou školní geografie by mělo být rozvíjení specifických znalostí, které žákům umožní uvědomělé zapojení do současné, dynamicky se rozvíjející společnosti. V rovině školy tomu odpovídají cílové domény školní geografie, které zde byly vymezeny v rovině kognitivní, afektivní a psychomotorické (kap. 1.3).

Cílové domény v oblasti kognitivní mají z hlediska školní geografie zásadní význam. Měly by směřovat k prohlubování myšlenkových operací žáků a rozvoji jejich představ a znalostí. Poznatky pedagogického výzkumu naznačují, že dosahování kognitivních cílových domén může být podpořeno, pokud žáci mají možnost konfrontovat své myšlenky s reprezentacemi učiva, které dokáží zobecňovat nejdůležitější aspekty učiva (např. Sumfleth \& Telgenbüscher, 2000, s. 60-61). V učebnicích (nejen školní geografie) tuto roli obvykle naplňují abstraktní nonverbální prvky, které strukturu geografických jevů, ale

11 Nižší hodnota indexu naznačuje, že zastoupení určité třídy je při srovnání mezi učebnicemi spíše nerovnoměrné a významněji se proto liší - variuje. Naopak vysoká hodnota indexu naznačuje, že zastoupení určité třídy je při srovnání mezi učebnicemi spíše rovnoměrné a odlišuje se tak v menší míře (podrobněji viz Řehák \& Řeháková, 1986, s. 66-69). 
také související principy a procesy dokáží přehledně znázorňovat ze své podstaty, např́klad blokdiagram znázorňující výškové vegetační stupně (srov. Einsiedler \& Martschinke, 1997, s. 13-17). Výsledky realizovaného šetření nicméně naznačily, že zastoupení abstraktních nonverbálních prvků je v učebnicích školní geografie poměrně různorodé. $V$ českých i německých učebnicích mají významné zastoupení, zároveň se ale analyzované učebnice u těchto typů v největší míře odlišují. U českých učebnic převládají tabelární typy nonverbálních prvků (např. tabulka), zatímco u německých se vyskytují spíše typy statisticko-grafové (např. graf). V celkovém pohledu je zastoupení abstraktních typů nonverbálních prvků rovnoměrněji zastoupeno u německých učebnic, ve srovnání s českými učebnicemi (Obrázek 1).

Podstatným zjištěním však je, že v českých a německých učebnicích školní geografie (obsahující sociálněgeografická témata) převažují obrazové typy nonverbálních prvků. Obrazové nonverbální prvky (např. fotografie savany, kresba znázorňující původní obyvatele Ameriky) zobrazují geografické jevy tak, jak vypadají ve skutečnosti, tj. analogicky. Lze je proto považovat za reprezentace učiva, které jsou blízké zkušenostem žáků a upoutávají tak jejich pozornost (např. Butler, 1994, s. 141). Vzhledem k jejich srozumitelnosti však tyto typy, bez doplňujícího komentáře (např. ze strany učitele, výkladového textu učebnice), nemusejí v dostatečné míře podporovat aktivní odvozování významů geografických jevů. V kontextu geografického vzdělávání tak lze usuzovat, že v analyzovaných učebnicích převládají nonverbální prvky, které na základě iluze reality, působivého dojmu a poddajné formy vybízejí k emocionálním učebním prožitkům a odkazují tak k cílovým doménám v oblasti afektivní. Zastoupení těchto typů nonverbálních prvků je markantní zejména u českých učebnic školní geografie, ve srovnání s učebnicemi německými (Tabulka 3).

Výuka školní geografie je formována i cílovými oblastmi v rovině psychomotorické. Rozvíjení zručnosti (např. při zacházení s pomůckami a zařrizeními) a šikovnosti (např̀ při využívání osvojených poznatků) nicméně není snadnou záležitostí a vyžaduje procvičování. Jako pomůcka se proto nabízí využívání reprezentací, které by umožňovaly znázorňovat více aspektů geografických jevů najednou a mohly tak sloužit jako „impuls“ pro učební aktivity. Jak však bylo zjištěno, kombinované nonverbální prvky, které v tomto ohledu mají největší potenciál, nebot' umožňují uchopovat geografické jevy vícero způsoby (Barth, 1963, s. 48-50), se v posuzovaných učebnicích vyskytují v poměrně nízké míře. $V$ českých učebnicích je pak jejich výskyt nižší, 
ve srovnání s učebnicemi německými. Potvrzuje se tak, že analyzované učebnice školní geografie (resp. jejich obrazové složky) nemusejí naplňování cílových domén $\mathrm{v}$ oblasti psychomotorické podporovat $\mathrm{v}$ plné míře.

Celkově se tak ukazuje, že z hlediska školní geografie a jejího cílového zaměření se v učebnicích pro vyšší stupeň sekundárního vzdělávání lze setkat převážně s typy nonverbálních prvků, které stimulují emocionální cítění žáků a mohou také motivovat k učebním aktivitám. Avšak abstraktní typy nonverbálních prvků, které by i přes vyšší kognitivní náročnost dokázaly na geografické jevy zprostředkovávat více strukturovaný pohled, se v posuzovaných učebnicích objevují spíše $\mathrm{v}$ menší míře. Jejich zastoupení v analyzovaných učebnicích je zároveň poměrně různorodé.

\section{$5 \quad$ Limity studie a diskuse výzkumných zjištění}

Studie se zaměřila na porovnání českých a německých učebnic školní geografie z hlediska typů nonverbálních prvků a interpretaci zjištění vzhledem k cílovým doménám daného vyučovacího předmětu. I když zvolený přístup $\mathrm{k}$ problematice přinesl cenné poznatky, vykazuje zároveň určité limity, které mohou podmiňovat validitu výzkumných zjištění. 0 jejich přiblížení se proto pokoušíme dále. $V$ návaznosti na vyjasňování metodiky výzkumné studie v kapitole usilujeme také o diskusi výzkumných zjištění a jejich zasazení do širšího kontextu reprezentovaného poznatky souvisejících výzkumů.

Vzhledem k operacionalizaci výzkumného problému (kapitola 3) nebylo ve studii například podrobněji zjišt’ováno obsahové zaměření nonverbálních prvků. Jak však uvádí Roseová (2008, s. 155-156), obsah nonverbálních prvků může významně podmiňovat možnosti jejich reálného uplatnění ve výuce. Zjištění studie by proto měla být interpretována spíše vzhledem $\mathrm{k}$ tomu, do jaké míry je zastoupení nonverbálních prvků v učebnicích (jako didaktických prostředků) v souladu s cílovým zaměřením školní geografie (jako vyučovacího předmětu). Nutno rovněž připustit, že ve studii byla při posuzování potenciálu nonverbálních prvků znázorňovat geografické učivo pozornost zaměřena na konkrétní charakteristiku - typ, zatímco ostatní charakteristiky (např. míra realističnosti či souvislost s textem) byly zohledňovány spíše v kontextu. Validita výzkumných zjištění byla do určité míry podmíněna i výběrem analyzovaného vzorku učebnic. Jeho rozsah lze považovat za vyhovující koncepci šetření, zároveň ale nedovoluje širší zobecňování výsledků. Do určité míry limitující však může být i samotná snaha o srovnávání 
učebnic školní geografie reprezentující odlišná pojetí geografického vzdělávání. Geografické vzdělávací obsahy totiž mohou být v odlišných pojetích uchopovány různě (např. Haubrich, 1982, s. 11), což může objektivnost posuzování nonverbálních prvků v učebnicích do určité míry snižovat.

Výsledky studie také $\mathrm{v}$ obecné rovině ukázaly, že v českých a německých učebnicích školní geografie je ke koncipování nonverbálních prvků přistupováno odlišným způsobem. Patrné je to nejen v zastoupení konkrétních typů, ale také ve vyváženosti tříd nonverbálních prvků. Zatímco v některých českých učebnicích se zastoupení nonverbálních prvků ukázalo jako poměrně jednostranné (viz Obrázek 1), v německých učebnicích bylo více vyvážené. Uvedená zjištění studie nicméně nejsou ojedinělá, nebot’ k obdobným závěrům dospěli i jiní autoři. Např́klad ve studii Erdmannové (2010) bylo zjištěno, že německé a francouzské učebnice dějepisu se tradičně odlišují v tom, jaké typy nonverbálních prvků žákům nabízejí pro účely interpretace učiva. Odlišné závěry ale přinesla studie Tangové (1994), která naznačila, že i když školní učebnice pocházejí z různých kulturních prostředí, obvykle vykazují srovnatelné zastoupení nonverbálních prvků.

Zároveň bylo zjištěno, že v aktuálních učebnicích školní geografie (domácích i německých) se při transformování geografických poznatků uplatňují především obrazové typy nonverbálních prvků. Ty jsou pro žáky obvykle srozumitelné, zároveň ale nemusejí vždy dostatečně vybízet $\mathrm{k}$ aktivizaci myšlenkových operací. Jejich uplatnění v rámci školní geografie se tak nabízí spíše v oblasti afektivních cílových domén. Naopak ostatní typy nonverbálních prvků, které by napomáhaly objasňování abstraktních geografických poznatků a současně umožňovaly dosahování cílových domén v oblasti kognitivní či psychomotorické, se v učebnicích vyskytovaly poměrně nevyváženě. Přičemž neuspokojivé bylo zejména nízké zastoupení kombinovaných nonverbálních prvků. Šetření také ukázalo, že zmiňované nedostatky v zastoupení nonverbálních prvků se týkají spíše českých učebnic školní geografie, ve srovnání s německými. I když uvedené poznatky nejsou př́liš lichotivé, korespondují se závěry jiných výzkumů, které naznačují, že využívání obrazových typů nonverbálních prvků při transformování vzdělávacích obsahů není charakteristické pouze pro učebnice školní geografie (Yasar \& Seremet, 2007), nýbrž se s ním lze setkat např́klad i v učebnicích školního dějepisu (Kleppe, 2010) či německého jazyka (Holzbrecher, 2010). 


\section{Závěr}

Povaha geografických fenoménů mnohdy nedovoluje, abychom se s nimi setkávali přímo. Jejich porozumění ve školní výuce je proto často podmíněno tím, jakým způsobem jsou žákům zprostředkovávány. Nahlédneme-li tedy výsledky studie shrnujícím pohledem, ukazuje se, že i když nonverbální prvky v aktuálních učebnicích školní geografie napomáhají při objasňování poznatků a mohou tak podporovat dosahování cílových domén školní geografie, není jejich potenciál $\mathrm{k}$ tomuto účelu využíván vždy v plné míře. Uvedená zjištění jsou závažná nejen z hlediska učebnic školní geografie a jejich fungování jako didaktických prostředků, ale také z hlediska explanace procesů učení žáků s učebnicemi. Zároveň ale poukazují na konkrétní aspekty, které by bylo možné v učebnicích školní geografie zlepšit. A mohou tak sloužit také jako východiska pro doporučení směrem $\mathrm{k}$ tvorbě učebnic.

Při snaze o další zlepšování českých učebnic školní geografie by se proto autoři výzkumů měli zaměřit především na vybalancování různých typů nonverbálních prvků, aby žákům nabídli vyváženější příležitosti k získávání nových poznatků (kognitivní doména), stejně jako rozvíjení postojů a hodnot (afektivní doména) a zároveň tak podpořili uplatňování geografických poznatků v každodenním životě (psychomotorická doména). Byl by tím naplněn jeden $\mathrm{z}$ důležitých předpokladů pro úspěšné směřování $\mathrm{k}$ cílovým doménám školní geografie. $V$ konkrétní rovině by pozornost měla být věnována strukturovaným a propracovaným typům nonverbálních prvků (blokdiagram, průřez), které díky svým vlastnostem dokáží geografické jevy zobecňovat a napomáhají tak jejich uchopování. Naopak zastoupení obrazových typů nonverbálních prvků v učebnicích (fotografie, kresby) by mělo být lépe promýšleno. Adekvátní by mělo být i zastoupení kombinovaných nonverbálních prvků, které mají z hlediska objasňování geografických poznatků nezanedbatelný potenciál, nebot’ mohou jasněji znázorňovat různé úhly pohledu a objasňovat vývoj geografických jevů.

V realizované studii jsme však byli schopni uchopit pouze dílčí aspekt složité problematiky nonverbálních prvků v učebnicích. Budoucí výzkumná šetření by se proto měla pokusit o zprostředkování poznatků, jež by bylo možné zobecňovat ve větší míře. Řešením by mohlo být například rozšíření výzkumné pozornosti o další charakteristiky nonverbálních prvků - sémantických, pragmatických ad. Prohloubení vypovídající hodnoty výzkumu by však mohlo pomoci i to, pokud by autoři výzkumů zasazovali svá zjištění př́ímo 
do kontextu vyučování a učení - např̀ porovnáním, jaké př́ležitosti k práci s různými nonverbálními prvky nabízejí učebnice s tím, jak je tato nabídka využívána učiteli a žáky v reálné výuce. Užitečné by bylo i ověřování, jaké preference ohledně využívání nonverbálních prvků v učebnicích mohou mít žáci a učitelé v zemích s odlišnými pojetími školně geografického vzdělávání.

\section{Literatura}

Barth, L. (1963). Bild und Karte im Erdkundeunterricht. Volk und Wissen. Berlin: Volkseigener Verlag.

Böhm-Kasper, O., Schuchart, C., \& Weishaupt, H. (2009). Quantitative Methoden in der Erziehungswissenschaft. Darmstadt: WBG.

Butler, D. R. (1994). Repeat photography as a tool for emphasizing movement in physical geography. Journal of Geography, 93(3), 141-151.

Cohen, L., Manion, L., \& Morrison, K. (2011). Research methods in education. London: Routledge.

Demirkaya, H. (2008). Using goal accomplishment style to predict geography academic achievement of prospective teachers. Electronic Journal of Social Sciences, 7(26), 281-305.

Einsiedler, W., \& Martschinke, S. (1997). Elaboriertheit und Strukturiertheit in Schulbuchillustrationen des Grundschulsachunterrichts, Nr. 86. Nürnberg: Institut für Grundschullforschung des Universität Erlangen.

Erdmann, E. (2010). Bilder in deutschen und französischen Geschichtsschulbüchern seit dem 19. Jahrhundert bis heute. In C. Heinze \& E. Matthes (Eds.), Das Bild im Schulbuch (s. 143-154). Bad Heilbrunn: Julius Klinkhardt.

Firth, R. (2011). Making geography visible as an object of study in the secondary school curriculum. The Curriculum Journal, 22(3), 289-316.

Greger, D. (2005). Proces schvalování učebnic v historickosrovnávací perspektivě. Pedagogická orientace, 15(3), 112-177.

Haubrich, H. (Ed.). (1982). International focus on geographical education. Braunschweig: Westermann.

Haubrich, H. (Ed.). (2006). Geographie unterrichten lernen. Die neue Didaktik der Geographie konkret. München: Oldenbourg.

Holzbrecher, A. (2010). Fotografie im interkulturell orientierten Fremdsprachenuterricht. In D. Caspari \& L. Koster (Eds.), Wege zu interkultureller Kompetenz (s. 29-38). Frankfurt am Main: Peter Lang.

Chráska, M. (2007). Metody pedagogického výzkumu. Základy kvantitatitvního výzkumu. Praha: Grada.

International Geographical Union (1992). International charter on geographical education. Washington: National Geographic Society.

Janko, T. (2012). Nonverbální prvky v učebnicích zeměpisu jako nástroj didaktické transformace. Brno: Masarykova univerzita.

Jennings, S. A. (2006). A content comparison of six physical geography textbooks spanning a century. International Research in Geographical and Environmental Education, 15(1), $1-14$. 
Kent, A., Lambert, D., Naish, M., \& Slater, F. (1996). Geography in education. Viewpoints on teaching and learning. Cambridge: Cambridge University Press.

Kleppe, M. (2010). Photographs in dutch History textbooks: Quantity, type and educational use. In C. Heinze \& E. Matthes (Eds.), Das Bild im Schulbuch (s. 261-272). Bad Heilbrunn: Julius Klinkhardt.

Levin, J. R. (1976). What have we learned about maximizing what children learn? In J. R. Levin \& V. L. Allen (Eds.), Cognitive learning in children. Theories and strategies (s. 105-134). New York: Academic Press.

Levin, J. R., \& Mayer, R. E. (1993). Understanding illustrations in text. In B. K. Britton, A Woodward, \& M. Binkley (Eds.), Learning from textbooks. Theory and practice (s. 95-113). Hillsdale: Lawrence Erlbaum Associates Publisher.

Macek, Z. (1984). Obraz jako didaktický prostředek. Pedagogika, 34(4), 453-469.

Maňák, J. (2008). Funkce učebnice v moderní škole. In P. Knecht \& T. Janík, et al., Učebnice z pohledu pedagogického výzkumu (s. 19-26). Brno: Paido.

Mikk, J. (2000). Textbook: Research and writing. Frankfurt: Peter Lang.

Peeck, J. (1993). Increasing picture effects in learning from illustrated text. Learning and Instruction, 3(3), 227-238.

Pešková, K. (2012). Vizuální prostředky pro výuku reálií: výsledky analýzy učebnic němčiny. Pedagogická orientace, 22(2), 243-265.

Řehák, J., \& Ǩeháková, B. (1986). Analýza kategorizovaných dat v sociologii. Praha: Academia.

Rose, G. (2008). Using photographs as illustrations in human geography. Journal of Geography in Higher Education, 31(1), 151-160.

Sénéchau, M. (2010). Sprechen auch Bilder verschiedene Sprachen? Illustrationen in Schulbuchkapiteln zu Kelten, Römern und Germanen in deutsch-französischen Vergleich. In C. Heinze \& E. Matthes (Eds.), Das Bild im Schulbuch (s. 125-142). Bad Heilbrunn: Julius Klinkhardt.

Sumfleth, E., \& Telgenbüscher, L. (2000). Zum Einflu $\beta$ von Bildmerkmalen und zusätzlichen Fragen zum Bild beim Chemie-lernen mit Hilfe von Bildern - Beispiel Massenspektrometrie. Zeitschrift für Didaktik der Naturwissenschaften, 6, 59-78.

Tang, G. M. (1994). Textbook illustrations: A cross-cultural study and its implications for teachers of language minority students. The Journal of Educational Issues of Language Minority Students, 13, 175-194.

Tracane, R. B., Ferreira, C., Ferreira, M. E., \& Carvalho, G. S. (2008). Analysing the theme of pollution in Portugese geography and biology textbooks. International Research in Geographical and Environmental Education, 17(3), 199-211.

Tollingerová, D. (1977). Audiovizuální prostředky a jejich psychologické parametry. In D. Tollingerová \& M. Cipro, Didaktická technika a pomůcky v socialistické škole. Díl 2. (s. 221-230). Praha: SPN.

Wahla, A. (1983). Strukturní složky učebnic geografie. Praha: SPN.

Wessel, A. E. (2010). Zur Rolle und Funktion von Bildern in Lehrbüchern des Finnischen als Fremdsprache. In C. Heinze \& E. Matthes (Eds.), Das Bild im Schulbuch (s. 233-248). Bad Heilbrunn: Julius Klinkhardt Verlag.

Woodward, A. (1993). Do illustrations serve an instructional purpose in U.S. textbooks? In B. K. Britton, A. Woodward, \& M. Binkley (Eds.), Learning from textbooks. Theory and practice (s. 115-134). Hillsdale: Lawrence Erlbaum Associates Publisher. 
Yang, D. (2011). A comparison of content in syllabus-based senior geography textbooks and standard-based senior geography textbooks in mainland China. International Research in Geographical and Environmental Education, 20(2), 121-138.

Yasar, 0., \& Seremet, M. (2007). A comparative analysis regarding pictures included in secondary school geography textbooks taught in Turkey. International Research in Geographical and Environmental Education, 16(2), 157-187.

\section{Autor}

Mgr. Tomáš Janko, Ph.D., Masarykova univerzita, Pedagogická fakulta, Institut výzkumu školního vzdělávání, Poříčí 31, 60300 Brno, e-mail: janko@ped.muni.cz

\section{A comparative analysis of types of visuals in current Czech and German human geography textbooks}

Abstract: The aim of the study is to compare the types of visuals (as means for didactical transformation of educational content) in Czech and German geography school textbooks and to interpret the results with regard to educational goals of school geography. First, the contemporary progress of geography school textbooks is contemplated which is implied by the arising complexity of geographical knowledge. Then the role played by textbook visuals in this context is described. The theory of textbooks and the concept of representation are used for explanation. Educational goals of school geography are also considered and subsequently used as context for interpretation of the results. Regarding the methodology, the study was realized as content analysis of 2 Czech and 2 German geography school textbooks (ISCED 2) in which 1140 visuals were analysed. The results showed that pictorial types of visuals (photo, realistic drawings) still predominate in current Czech school textbooks. In German school textbooks, however, the distribution of the types of visuals is better balanced. It could be therefore concluded that in Czech geography school textbooks the types of visuals which may encourage pupil's emotional reactions towards educational content predominate, but these facilitate cognitive elaboration of content only to a limited extent. They may thus serve as didactical means for educational goals in affective domain, rather than in cognitive or psychomotoric domain.

Keywords: geography, textbooks, visuals, visual representations, comparative analysis, didactical transformation 